\title{
PERBEDAAN PERSENTASE PEMBERIAN RANSUM ANTARA SIANG DAN MALAM TERHADAP PERFORMA AYAM JANTAN TIPE MEDIUM DI KANDANG POSTAL
}

\section{The Different Percentage of Ration Between Day and Night Given to Performance of Male Chicken Medium Type in Chicken Coop}

\author{
Khaira Nova, Riyanti, Dian Septinova, Purnama Edy Santosa \\ Department of Animal Husbandry, Faculty of Agriculture, University of Lampung \\ Soemantri Brojonegoro No. 1 Gedong Meneng, Bandar Lampung 35145 \\ Email:novakhaira@gmail.com
}

\begin{abstract}
The objective of this experiment was to determine the effects of different percentage of ration between day and night to male chicken medium type performance; the best level of percentage of ration that given between the day and night in chicken coop. A total of one hundred and forty four day-old male chicks medium type were divided into 3 treatments and 6 replications, each treatment consist of 8 male chickens. The treatments were ration that given $30 \%$ during the day and $70 \%$ the night; ration that given $50 \%$ during the day and 50\% the night; ration that given $70 \%$ during the day and $30 \%$ the night. This research was conducted from August through October 2018 in Integrated Laboratory Department of Animal Husbandry, Faculty of Agriculture, University of Lampung. Data were subjected to analysis variance. Significant was considered at 5\% level of probability. The results showed, percentage ration between day and night signicant influence feed consumption $(P<0.05)$, but not significant effect to body weight and feed conversion ratio. The percentage of ration given $30 \%$ during day and $70 \%$ night is the best treatment influence feed conversion ratio (2,41) with feed consumption $1.738 .03 \mathrm{~g} / \mathrm{bird}$ and body weight 718,58 g/bird.
\end{abstract}

Keywords : Male chickens, Ration percentage, Chicken coop

\section{PENDAHULUAN}

Daging ayam banyak digemari masyarakat dan mempunyai keunggulan memberikan konstribusi untuk memenuhi kebutuhan protein hewani untuk pertumbuhan manusia. Daging ayam yang dikonsumsi berasal dari daging broiler dan daging ayam kampung. Alternatif daging ayam dapat diperoleh dari ayam jantan tipe medium yang merupakan hasil yang tidak diharapkan dari usaha penetasan ayam petelur, karena hanya ayam betina yang dipasarkan untuk dapat diambil produksi telurnya (Nova, 2009).

Ayam jantan tipe medium mempunyai beberapa kelebihan jika digunakan sebagai sumber ayam pedaging antara lain harga anak ayam umur sehari jauh lebih murah, dagingnya mengandung kadar lemak sedikit serta rasanya mirip rasa daging ayam kampung. Hal ini menarik minat konsumen untuk mengonsumsinya.
Ayam jantan tipe medium khususnya di Lampung banyak dipelihara pada kandang postal (kandang litter) dan kandang panggung. Kedua tipe kandang ini mempunyai kelebihan dan kekurangan. Menurut Mulyantini (2010), litter adalah bahan yang digunakan di atas lantai kandang yang memberikan media yang nyaman untuk kehidupan ayam, bahan litter dapat berupa sekam padi, serbuk gergaji, serutan kayu, potongan-potongan jerami dan rumput kering. Kandang postal adalah kandang yang dengan alas lantai yang padat beralaskan litter; dinding kandang disemen setinggi $75 \mathrm{~cm}$ dari atas lantai dasar; suhu kandang lebih tinggi karena kurangnya sirkulasi udara; biaya pembuatan kandang lebih murah namun kurang nyaman bagi unggas karena ayam mudah stres akibat panasnya litter saat ayam sudah lepas fase brooding.

Pemeliharaan ayam jantan tipe medium di kandang postal banyak mengalami cekaman karena iklim Indonesia yang tropika basah, membuat suhu di sekitar kandang tinggi. Suhu 
ideal pada pemeliharaan ayam $10-22^{\circ} \mathrm{C}$ untuk pencapaian berat badan optimum dan $15-27^{\circ} \mathrm{C}$ untuk efisiensi ransum. Suhu yang tinggi akan menurunkan konsumsi ransum dan ayam akan meningkatkan konsumsi air minum untuk mengimbangi suhu tubuhnya. Hal ini akan memengaruhi pertumbuhan ayam. Menurut AlFataftah dan Abu-Dieyeh (2007), suhu yang tinggi membuat reseptor termal perifer memberikan impuls saraf penekan ke pusat nafsu makan di hipotalamus sehingga terjadi penurunan konsumsi ransum, maka guna memperbaiki performa unggas di kandang postal diperlukan perbaikan manajemen pemeliharaan agar unggas tetap bisa tumbuh maksimum menampilkan kemampuan produksinya.

Performa pertumbuhan ayam yang dipelihara di kandang postal bisa diperbaiki lebih baik melalui banyak hal, salah satunya dengan perbaikan manajemen pemberian ransum yakni dengan cara mengubah metode pemberian ransum. Manipulasi pemberian ransum untuk mengimbangi feed intake yang kurang optimal pada siang hari karena suhunya tinggi dan melakukan pemberian ransum yang lebih banyak saat suhu lingkungan mulai turun pada malam hari dapat dijadikan alternatif solusi untuk mempertahankan perfoma ayam jantan tipe medium. Menurut Nova (2017), faktor lingkungan yang juga besar pengaruhnya pada pertumbuhan adalah ransum selain iklim dan tata laksana pemeliharaan. Menurut Mulyantini (2010), ada beberapa faktor yang memengaruhi konsumsi pakan, diantaranya adalah bangsa dan strain unggas, suhu lingkungan, bobot tubuh, jenis kelamin, umur, jenis kandang, kandungan energi dari pakan, dan tingkat stres.

Pemberian persentase ransum yang lebih banyak di malam hari saat udara sejuk, akan menyebabkan ayam merasa nyaman untuk mengonsumsi ransum dan terhindar dari panas karena lingkungan ataupun panas dari hasil metabolisme ransum yang dikonsumsinya. Hasil penelitian Nova (2017), ayam jantan tipe medium di kandang panggung lebih baik konsumsi ransum (1.545,39 g/ekor), bobot badan akhir (762,08 g/ekor) dan feed conversion ratio/FCR $(2,03)$ dengan metode persentase pemberian ransum $30 \%$ siang dan $70 \%$ malam hari. Ransum yang lebih banyak diberikan pada malam hari saat suhu rendah, dikonsumsi ayam lebih sedikit dengan hasil bobot badan akhir yang lebih besar sehingga Feed Conversion Ratio (FCR) menjadi lebih kecil.

Selama ini belum ada informasi tentang berapa level terbaik untuk ayam jantan tipe medium di kandang postal diberikan persentase ransum untuk siang dan malam hari. Oleh sebab itu, penelitian ini dilakukan dengan pemberian ransum $30 \%$ siang dan $70 \%$ malam (R1); $50 \%$ siang dan $50 \%$ malam (R2); $70 \%$ siang dan $30 \%$ malam (R3) untuk mencari persentase pemberian ransum siang dan malam yang terbaik terhadap konsumsi ransum, bobot badan akhir, FCR ayam jantan tipe medium di kandang postal.

\section{MATERI DAN METODE}

\section{Materi}

Anak ayam jantan tipe medium umur sehari strain lohman brown sabanyak 144 ekor, dipelihara dari umur sehari sampai umur 7 minggu pada petak kandang postal yang terbuat dari bambu, beralaskan sekam padi sebagai litter dengan ketebalan $8 \mathrm{~cm}$. Kepadatan kandang terdiri dari 8 ekor/0,5 $\mathrm{m}^{2}$. Ransum yang digunakan adalah ransum broiler komersial BBR1 dengan kadar protein $20 \%$ dan energi metabolis $3.200 \mathrm{kkal} / \mathrm{kg}$. Peralatan yang dipakai adalah brooder, baby chick feeder, tempat minum, timbangan, termohygrometer, sekat kandang, lampu penerang, perlengkapan kebersihan dan alat tulis.

\section{Metode}

Rancangan penelitian ini adalah Rancangan Acak Lengkap, terdiri atas 3 perlakuan dan 6 ulangan, setiap ulangan terdiri atas 8 ekor ayam. Perlakuan yang diberikan adalah R1 (pemberian ransum 30\% siang dan $70 \%$ malam), R2 (pemberian ransum $50 \%$ siang dan $50 \%$ malam), R3 (pemberian ransum $70 \%$ siang dan $30 \%$ malam ). Peubah yang diamati adalah konsumsi ransum, bobot badan akhir, dan feed conversion ratio. Analisis ragam digunakan untuk analisis data pada taraf nyata $5 \%$ dan uji lanjut menggunakan uji Duncan (Steel dan Torrie, 1993).

Penelitian dilaksanakan di kandang Laboratorium Terpadu, Fakultas Pertanian Unila, Agustus sampai Oktober 2018. Pelaksanaan penelitian dimulai dengan membersihkan dan mensucihamakan kandang, membuat area brooding, pemasangan sekat. Pemeliharaan fase brooding selama 1-14 hari; pemberian ransum dan air minum terus menerus; lampu penerangan dihidupkan malam hari; suhu lingkungan dan kelembaban diukur empat kali sehari; program vaksinasi dilakukan terhadap penyakit New Castle Disease, Avian Influenza dan Infectious Bursal Disease.

Perlakuan persentase pemberian ransum siang dan malam diterapkan setelah ayam berumur 2 minggu. Peubah yang diukur adalah 
(1) konsumsi ransum yang dihitung adalah jumlah ransum yang dikonsumsi ayam selama 7 minggu (g) ; (2) bobot badan akhir diukur bobot tubuh ayam jantan medium saat dipanen umur 7 minggu; (3) Feed Conversion Ratio (FCR) dihitung berdasarkan jumlah ransum yang dimakan selama 7 minggu dibagi dengan bobot badan akhir.

\section{HASIL DAN PEMBAHASAN}

\section{Konsumsi Ransum}

Rata-rata konsumsi ransum ayam jantan tipe medium berkisar antara 1.738,03--1.819,84 g/ekor seperti tertera pada Tabel 1. Berdasarkan analisis ragam, konsumsi ransum ayam jantan tipe medium nyata dipengaruhi oleh perlakuan persentase pemberian ransum antara siang dan malam hari $(\mathrm{P}<0,05)$. Uji Duncan memperlihatkan bahwa konsumsi ransum ayam jantan tipe medium pada persentase pemberian ransum $30 \%$ siang dan $70 \%$ malam $(1.738,03$ g/ekor) nyata lebih rendah dibandingkan dengan konsumsi ransum pada perlakuan persentase pemberian ransum $50 \%$ siang dan $50 \%$ malam $(1.799,04$ g/ekor) dan persentase pemberian ransum $70 \%$ siang dan $30 \%$ malam $(1.819,84$ g/ekor). Namun, konsumsi ransum ayam jantan tipe medium pada persentase pemberian ransum $50 \%$ siang dan $50 \%$ malam tidak berbeda nyata dengan perlakuan persentase pemberian ransum $70 \%$ siang dan $30 \%$ malam.

Tabel 1. Rata-rata konsumsi ransum ayam jantan tipe medium selama penelitian (Average of ration consumption of male chicken medium type)

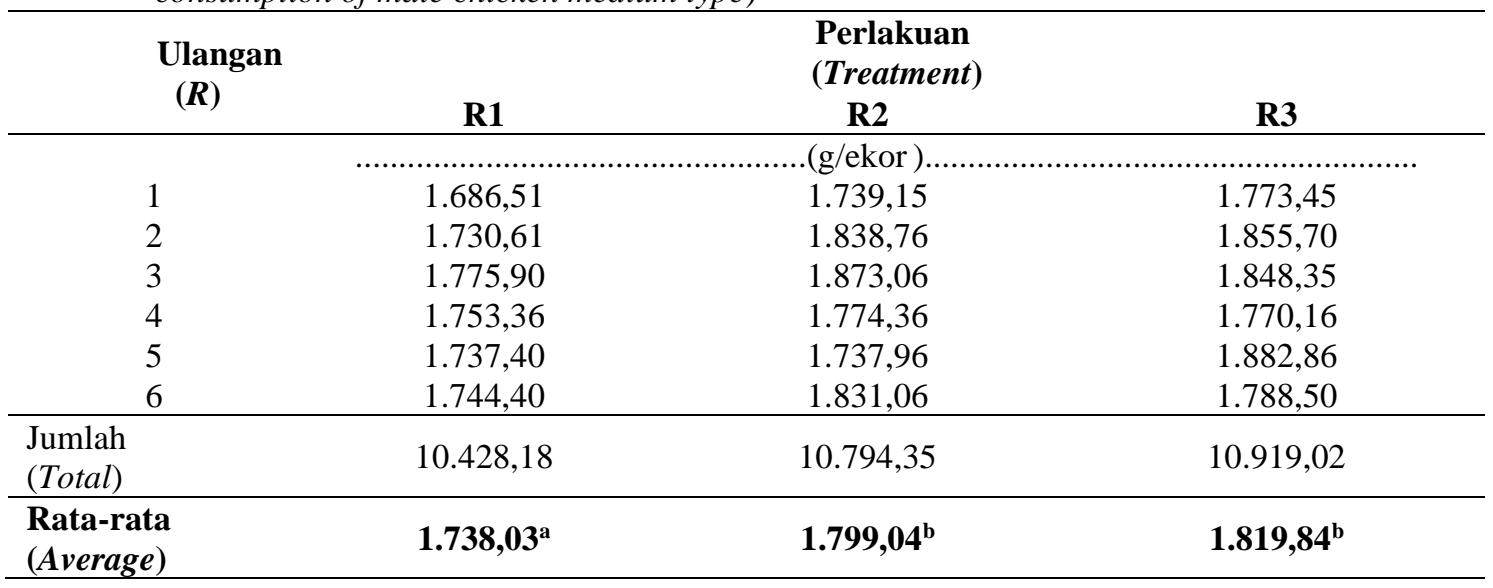

Keterangan:

R1 : Persentase pemberian ransum $30 \%$ siang dan $70 \%$ malam

R2 : Persentase pemberian ransum 50\% siang dan 50\% malam

R3 : Persentase pemberian ransum $70 \%$ siang dan $30 \%$ malam

Superscript yang berbeda dalam baris rata-rata menunjukkan berpengaruh nyata $(\mathrm{P}<0,05)$.

Pada pemberian ransum $30 \%$ siang dan $70 \%$ malam, konsumsi ransum ayam jantan tipe medium yang rendah mampu memberikan FCR yang lebih rendah dibandingkan dengan perlakuan lainnya (Tabel 3), walaupun belum berdampak nyata terhadap bobot badan akhir. Hal ini membuktikan bahwa ayam jantan tipe medium yang dipelihara di kandang postal merasakan cekaman panas yang sama baik siang ataupun malam hari, sehingga walaupun ransum disediakan di malam hari lebih banyak saat suhu sejuk, ayam tetap tidak sanggup makan lebih banyak lagi karena panas dari kandang postal sehingga konsumsi ransumnya rendah. Hasil ini berbeda dengan penelitian di kandang panggung oleh Nova (2017) bahwa ayam jantan tipe medium mengonsumsi ransum lebih banyak ketika ransum diberikan $70 \%$ malam dan $30 \%$ siang. Hal ini karena pada suhu penelitian di kandang panggung lebih sejuk dibandingkan kandang postal. Pada kandang panggung, udara mengalir dari seluruh sisi kandang dan dari bawah kandang karena lantai kandang yang bercelah.

Konsumsi ransum yang rendah pada pemberian ransum $30 \%$ siang dan $70 \%$ malam diduga karena terganggunya fungsi fisiologis ayam karena panas yang tidak jauh berbeda antara siang $\left(28,51^{\circ} \mathrm{C}\right)$ dan malam $\left(26,21^{\circ} \mathrm{C}\right)$ di kandang postal dan diiringi oleh kelembaban yang tinggi (78\%). Menurut Cahyono (2004), ayam yang fungsi fisiologisnya bekerja secara baik, akan menggunakan ransum yang dikonsumsinya untuk pertumbuhan dengan sebaik-baiknya. Xu et al. (2018) menyatakan bahwa dalam kondisi stres 
panas fisiologi dan immunologi ayam terganggu. Menurut Piliang (2000), beberapa faktor yang memengaruhi konsumsi ransum adalah bobot badan, jenis kelamin, fase pertumbuhan, suhu lingkungan palatabilitas ransum, bentuk fisik ransum, dan keseimbangan hormonal.

Konsumsi ransum pada perlakuan persentase pemberian ransum 50\% siang dan 50\% malam $(1.799,04$ g/ekor) tidak berbeda nyata dengan konsumsi ransum pada perlakuan persentase pemberian ransum $70 \%$ siang dan $30 \%$ malam (1.819,84 g/ekor). Hal ini diduga karena pada kedua perlakuan ini ransum banyak diberikan pada siang hari, ayam tetap memakannya tapi banyak energi yang dimakan terbuang untuk melawan suhu panas di siang hari (rata-rata suhu saat penelitian $28,51^{\circ} \mathrm{C}$ ) sehingga efisiensi ransum rendah. Hal ini seperti terlihat dalam penelitian ini dengan tingginya FCR pada perlakuan persentase pemberian ransum $50 \%$ siang dan $50 \%$ malam maupun perlakuan persentase pemberian ransum $70 \%$ siang dan $30 \%$ malam. Charles (2002) menyatakan bahwa suhu optimum untuk ayam tumbuh $18-22^{\circ} \mathrm{C}$, selain itu suhu yang tinggi di siang hari akan menyebabkan kortikosteron dalam darah meningkat dan mengakibatkan efisiensi ransum menjadi rendah. Menurut Abbas (2009), semua penyebab stres oleh suhu lingkungan tinggi meningkatkan kortikosteron dalam darah akan merendahkan efisiensi ransum. Menurut Olfati et al. (2018), stres memengaruhi produksi unggas melalui pengaruh metabolisme nutrisi dan pencernaan yang juga akan meningkatkan kortikosteron dalam darah.

\section{Bobot Badan Akhir}

Tabel 2 memperlihatkan rata-rata bobot badan akhir ayam jantan tipe medium berkisar antara 718,58 dan 731,85 g/ekor. Hasil analisis ragam menunjukkan perlakuan tidak berpengaruh nyata $(\mathrm{P}>0,05)$ terhadap bobot badan badan akhir ayam jantan tipe medium.

Tabel 2. Rata-rata bobot badan akhir ayam jantan tipe medium selama penelitian (Average live bird of male chicken medium type)

\begin{tabular}{lllll}
\hline \multirow{2}{*}{$\begin{array}{l}\text { Ulangan } \\
(\mathbf{R})\end{array}$} & \multicolumn{3}{c}{$\begin{array}{c}\text { Perlakuan } \\
\text { (Treatment) }\end{array}$} \\
\cline { 3 - 5 } & & $\mathbf{R} 1$ & $\mathbf{R 2}$ & $\mathbf{R 3}$ \\
& 1 & 764,13 & 731,63 & 731,88 \\
& 2 & 714,88 & 736,13 & 776,13 \\
& 3 & 716,00 & 763,13 & 731,88 \\
& 4 & 712,50 & 707,88 & 730,50 \\
& 5 & 691,13 & 739,13 & 701,25 \\
\hline Jumlah & 6 & 712,88 & 712,38 & 719,50 \\
$($ Total $)$ & $4.311,50$ & $4.390,25$ & $4.391,13$ \\
\hline Rata-rata & & $\mathbf{7 1 8 , 5 8}$ & $\mathbf{7 3 1 , 7 1}$ & $\mathbf{7 3 1 , 8 5}$ \\
$($ Average $)$ & & & & \\
\hline
\end{tabular}

Keterangan:

R1 : Persentase pemberian ransum $30 \%$ siang dan $70 \%$ malam

R2 : Persentase pemberian ransum $50 \%$ siang dan $50 \%$ malam

R3 : Persentase pemberian ransum $70 \%$ siang dan $30 \%$ malam

Bobot badan akhir ayam yang tidak berbeda nyata ini diduga disebabkan oleh ransum yang dikonsumsi ayam dengan pemberian ransum yang lebih banyak pada siang hari maupun malam hari tidak mampu dimetabolisme sebaik-baiknya menjadi pertumbuhan ayam karena suhu di kandang postal yang tinggi baik saat siang ataupun malam hari. Litter sebagai alas kandang yang kontak langsung dengan tubuh ayam memberikan panas yang juga bisa mengganggu fungsi fisiologis ayam saat sudah lepas brooding. Litter di masa brooding litter sangat dibutuhkan untuk menghangatkan ayam namun setelah ayam tumbuh bulu lengkap sebaiknya ayam tidak lagi kontak dengan litter. Hal inilah salah satu kelemahan kandang postal yang beralaskan litter yaitu ayam tetap berada diatas litter sampai ayam siap panen. Ayam merasa panas dan tidak maksimum manampilkan performanya melalui indikator bobot badan akhir. Keadaan ini mengganggu keseimbangan enzim-enzim yang dihasilkan oleh tubuh dengan zat-zat nutrisi yang dikonsumsi ayam. 
Menurut Rasyaf (2011), proses pencernaan dan penyerapan zat-zat nutrisi dalam bahan makanan terutama protein oleh tubuh ayam berlangsung secara sempurna apabila terjadi keseimbangan antara enzim yang dihasilkan oleh tubuh dengan jumlah zat-zat nutrisi yang dikonsumsi ayam tersebut, tetapi jika suhu naik terlalu tinggi lebih dari $28^{\circ} \mathrm{C}$ maka terjadi denaturasi protein yang cepat sehingga produksi enzim di dalam tubuh ayam menurun, sehingga banyak zat-zat nutrisi yang tidak tercerna secara sempurna dan tidak akan terserap oleh tubuh serta hanya terbuang sebagai feses.

Rata-rata bobot badan akhir pada penelitian di kandang postal ini lebih rendah jika dibandingkan dengan rata-rata bobot badan akhir pada kandang panggung yang berkisar 735,63 dan 762,08 g/ekor (Nova, 2017). Perbedaan ini disebabkan oleh tipe kandang yang digunakan, jumlah konsumsi ransum selama penelitian. Kandang postal pada penelitian ini terbukti suhunya siang hari lebih panas $\left(28,51^{\circ} \mathrm{C}\right)$ dibandingkan dengan kandang panggung di siang hari $\left(25,58^{\circ} \mathrm{C}\right)$ sehingga ransum yang dikonsumsi ayam jantan tipe medium pun menjadi kurang efisien untuk digunakan sebagai pertumbuhan ayam sehingga bobot badannya jadi lebih rendah di kandang postal. Rendahnya bobot badan akhir ini diduga disebabkan oleh kemampuan aktivitas kelenjar tiroid yang menurun pada suhu yang tinggi dalam menghasilkan hormon tiroksin yang dibutuhkan untuk pertumbuhan sehingga pertumbuhannya lebih rendah di kandang postal yang suhunya lebih panas. Menurut Abbas (2009), pada malam hari saat suhu lingkungan rendah, aktivitas dari kelenjar tiroid dapat menghasilkan hormon tiroksin secara maksimum. Fungsi utama hormon tiroksin untuk meningkatkan metabolisme dan penyerapan nutrisi sehingga absorpsi zat-zat makanan di dalam usus akan meningkat maka laju pertumbuhan akan meningkat. Kelenjar tiroid tidak mampu menghasilkan hormon tiroksin secara maksimal pada siang hari yang suhunya tinggi. Hal ini mengakibatkan menurunnya laju pertumbuhan ayam.

\section{Feed Conversion Ratio}

Menurut Fadilla (2005), feed conversion ratio (FCR) adalah banyaknya ransum yang dikonsumsi untuk menghasilkan satu kilogram bobot ayam hidup. Rata-rata FCR penelitian ini berkisar antara 2,41-2,48 (Tabel 3). Berdasarkan analisis ragam perlakuan berpengaruh tidak nyata $(\mathrm{P}>0,05)$ terhadap FCR ayam jantan tipe medium.

Tabel 3. Rata-rata feed convertion rate (FCR) ayam jantan tipe medium selama penelitian (Average offeed convertion ratio of male chicken medium type)

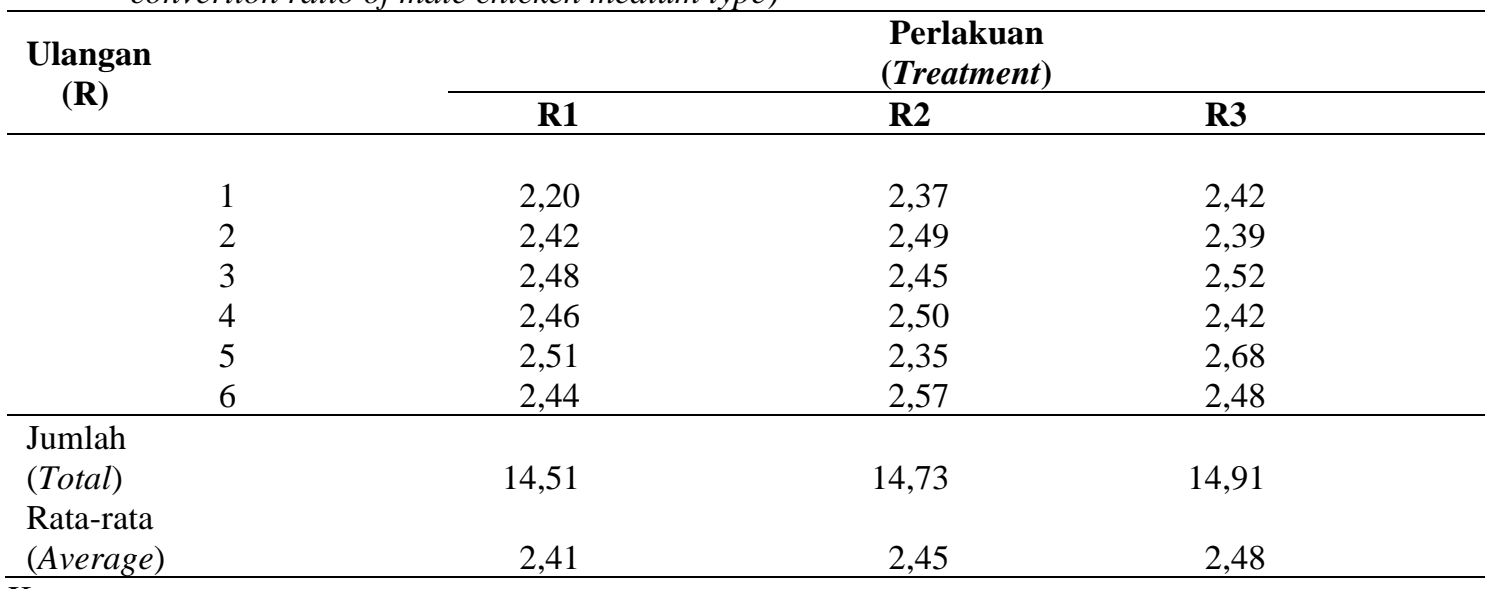

Keterangan:

R1 : Persentase pemberian ransum $30 \%$ siang dan $70 \%$ malam

R2 : Persentase pemberian ransum $50 \%$ siang dan $50 \%$ malam

R3 : Persentase pemberian ransum $70 \%$ siang dan $30 \%$ malam

Feed conversion ratio yang cenderung rendah pada persentase pemberian ransum $30 \%$ siang dan $70 \%$ malam membuktikan ransum yang dikonsumsi ayam lebih efisien diubah menjadi bobot badan. Hal ini disebabkan oleh banyaknya ransum yang diberikan di malam hari dibandingkan dengan siang hari. Ayam merasa nyaman mengonsumsi ransum di malam hari yang sejuk sehingga fungsi fisiologis tubuhnya bekerja dengan baik dalam mencerna makanan dan mengubahnya menjadi energi yang dibutuhkan tubuh untuk pertumbuhannya. Menurut Rasyaf 
(2011), nilai konversi ransum yang rendah menunjukkan ransum lebih efisien, sebaliknya nilai konversi ransum yang tinggi, menunjukkan ransum kurang efisien digunakan ayam untuk pertumbuhannya. Hal ini karena semakin banyak ransum yang dibutuhkan untuk menaikkan bobot badan akhir.

Feed conversion ratio yang cenderung lebih besar pada ransum yang banyak diberikan pada siang hari, semakin membuktikan bahwa suhu sangat memengaruhi konversi ransum yang kurang efisien walaupun ransum yang dikonsumsi banyak karena ransum yang diberikan banyak di siang hari, diikuti juga dengan bobot yang relatif tinggi, namun konsumsi ransum yang banyak tidak dapat menyebabkan FCR semakin rendah karena ransum yang dikonsumsi tidak dikonversikan dengan baik menjadi bobot badan ayam. Hal ini karena panasnya suhu di siang hari merupakan cekaman tersendiri bagi ayam yang menyebabkan ayam terengah-engah, disamping cekaman panas oleh metabolisme dari ransum yang banyak dimakan ayam. Hal inilah yang menyebabkan FCR menjadi lebih besar. FCR yang besar mengindikasikan bahwa ransum yang dikonsumsi kurang efisien untuk menghasilkan bobot badan akhir ayam jantan tipe medium. Hal ini disebabkan oleh ransum yang sama-sama banyak dikonsumsi pada siang hari tidak digunakan sepenuhnya untuk pertumbuhan, namun digunakan juga untuk melawan suhu panas yang datang dari lingkungan di siang hari, sehingga ayam banyak membuang energi untuk penyesuaian suhu tubuhnya dengan lingkungan. Rasyaf (2011) mengemukakan ayam yang mengonsumsi sejumlah ransum dan mampu mengubahnya untuk menunjang pertumbuhannya yang cepat, menandakan efisiensi penggunaan ransum yang baik.

\section{SIMPULAN DAN SARAN}

\section{Simpulan}

Persentase pemberian ransum antara siang dan malam mempengaruhi konsumsi ransum, tidak berpengaruh terhadap bobot badan akhir dan feed conversion ratio (FCR). Persentase pemberian ransum $30 \%$ siang dan $70 \%$ malam memberikan pengaruh terbaik untuk feed conversion ratio (FCR) yakni 2,41 dengan konsumsi ransum 1.738,03 g/ekor dan bobot badan akhir 718,58 g/ekor

\section{Saran}

Peternak yang memelihara ayam jantan tipe medium secara komersial di kandang postal disarankan memberikan ransum $30 \%$ siang dan $70 \%$ malam.

\section{UCAPAN TERIMAKASIH}

Terima kasih penulis ucapkan kepada Ryan Nastiansyah, Angga Prasetyo Kurniawan, Defti Ayu Sumadi, dan Evelin Dea yang telah membantu kelancaran penelitian ini. Semoga menjadi amal shalih.

\section{DAFTAR PUSTAKA}

Abbas, M. H. 2009. Fisiologi Pertumbuhan Ternak. Andalas University Press. Padang

Al-Fataftah, A. A, and A. Dieyeh. 2007. Effect of chronic heat stress on broiler performance in Jordan. Int. J. Poult. Sci. 6 (1) : 64-70

Cahyono, B. 2004. Cara Meningkatkan Budidaya Ayam Ras Pedaging. Cetakan pertama. Yayasan Pustaka Nusantara. Yogyakarta.

Charles, D. R. 2002. Responses to the thermal environment. In : Poultry Environment Problems, a Guide to Solution. Charles and Walker (eds). Nottingham University Press. United Kingdom. Pp. 1-16

Mulyantini, N. G. A. 2010. Ilmu Manajemen Ternak Unggas. Gadjah Mada University Press. Yogyakarta.

Nova, K., Tintin, K., Riyanti., dan Purnama, E. S. T. 2009. Pengaruh Kepadatan Kandang Terhadap Respon Fisiologis dan Performan Ayam Jantan Tipe Medium. Laporan Penelitian. Universitas Lampung. Bandar Lampung.

Nova, K. 2017. Performa Ayam Jantan Tipe Medium dengan Persentase Pemberian Ransum yang Berbeda antara Siang dan Malam Hari. Prosiding Seminar Nasional Teknologi Pertanian VI. Bandarlampung

Olfati, A., A. Mojtahedin., T. Sadeghi,. M. Akbari., F. Martinez. 2018. Comparison of growth performance and immune response of broiler chicks reared under heat stress, cold stress and thermoneutral condition. Spanish J. of Agr. Research 16 (2): 505 .

Piliang W.G. 2000. Fisiologi Nutrisi. Volume I. Institut Pertanian Bogor. Bogor

Rasyaf, M. 2011. Panduan Beternak Ayam Pedaging. Cetakan ke-4. Penebar Swadaya. Jakarta.

Steel, R. G. D. dan J. H. Torrie. 1993. Prinsip dan Prosedur Statistik (terjemahan Principle and Procedure of Statistics oleh B. 
Sumantri). Gramedia Pustaka Utama. Jakarta

Xu, Y., Xiaodan, L., Zhipeng, L., Xiquan, Z., and Qingbin, L. 2018. Effect of chronic stress on some physiological and immunological parameters in different breed of broilers. Poultry Sci. 97 : 4073 4082 . 